\title{
The Concept of Military Law Development in Indonesia
}

\author{
Wahyoedho Indrajit \\ \{wahyoedo49@gmail.com\} \\ ${ }^{1}$ Jayabaya University, Jakarta, Indonesia
}

\begin{abstract}
Military law in force in Indonesia today is a legacy from the Dutch East Indies Colonial Government in the form of Wetboek van Militair Strafrech and Wet op de Krigstucht which currently causes many problems among Soldiers because of the structure, substance and culture of the law based on the law the colonial law system. The concept of military law development in Indonesia is carried out by building structures, culture and substance. The development of law structure refers to institutions that form and implement law (law enforcement), the development of law culture refers to assessing and expectations of the military community and the development of the substance of military law is carried out by establishing military law norms, both disciplinary norms law, criminal law, procedural law, military criminal law, military administrative law and military civil law.
\end{abstract}

Keyword: Military law, development, soldiers.

\section{Introduction}

Military law grows and develops along with the development of military society which is very closely related to war. War refers to a condition which is no longer controlled by law but rather the use of gun violence carried out by the army. The war is always associated with destruction, murder, plunder or acts of violence to win the war. In World War II, Adolf Hitler stated that "the victor shall not be asked later on whether we told the truth or not. In starting and making war, not the right is what matters, but victory."[1]. The victor of the war will not be asked whether he will tell the truth or not. In war, it is not a right which is important, but victory is.

Military law was issued for the need of the military community to regulate its members to be obedient to every leader's orders. Each member of the military is required to always be disciplined in carrying out training, discipline in obeying the rules issued by the leadership including being disciplined when carrying out war orders so that strict norms are needed to foster soldiers' obedience to the law.

Initially, military law did not have its own place in public and private law. However, bearing in mind that the importance of legal issues that apply specifically to members of the military who have a very heavy duty, i.e. securing the country's sovereignty, maintaining territorial integrity, and protecting the entire nation and all of Indonesia's people, military law needs to be issued. Military life which is very hard and full of discipline requires special and specific rules so that the law is also adjusted to the duties carried out by members of the military. Therefore, special and specific laws are needed in the fields of disciplinary, criminal, 
criminal procedure, constitutional law, administrative law or law military administration, including military civil law.

The embryo of military law that grew and developed in Indonesia today originated from the Swiss Military Law which was created in 1393 under the name Kriegsordnung, known as Sempacherbrief. In 1532, Emperor Charles V of Germany issued a Kriegsartikel which was named the Constitutio Criminalist of Carolina used as a model of military law by European countries. In 1536, Hertog Karel van Gelre issued Artticulbrief, and in 1621, King Gustav Adolf of Sweden issued a Criegarticle which was valid for all infantry, cavalry, and artillery troops. The Swedish king realized that victory on the battlefield was not only determined by the strength of weapons, military tactics, but was also determined by the discipline of the troops supported by adequate legal rules.

Towards the end of the XVII century, Napoleon succeeded in codifying military law under the name Code Penal Militair and succeeded in building a strong army with morale and high discipline. In 1799, the Dutch succeeded in compiling the Crimineel Wetboek voor de Militair van Staat (Book of Military Criminal Law) which modeled on the Penal Code Penal Militair of Napoleon. In 1815, the Crimineel Wetboek voor het Krijgsvolk te Lande (the Criminal Code for the Army) was issued, and in 1903, the concept of Wetboek van Militair Strafrecht was created by Prof. van der Hoeve. In 1923, Wetboek van Miltair Strafrech (Military Criminal Code/KUHPM) was enacted in force for the Dutch Army and Navy and Wet op de Krigstucht (Military Disciplinary Code/KUHDM) was also enacted. In 1934, KUHPM and KUHDM were promulgated by Staatblad 1934 No. 167 and 168 which came into force on October 1, 1934 by Decree of the Governor General on March 25, 1934 Staatblad 1934 No. 337.

After Indonesian independence, Wetboek van Militair Strafrecht (KUHPM) was ratified by the Law No. 39/1947 and Wet op de Krigstucht (KUHDM) was ratified by the Law No. 40/1947 that was valid for the entire Indonesian Military. Whereas the Army court was formed by Law No. 7 of 1946, the Military Criminal Procedure Code was established by Law No. 8 of 1946 and the Army Court was formed by Law No. 31 of 1947 and the Military Imprisonment was formed by Law No. 47 of 1947. In 1997, 2 (two) Military Laws were successfully amended, namely Military Discipline Law with Law No. 26/1997 and Military Courts Law with Law No. 31/1997 which is still in force. In 2014, the Military Disciplinary Law was amended by the Law No. 25/2014.

Based on the history of the formation and enactment, the military law in Indonesia is very ancient and is a product of the Dutch Colonial Government which is still valid until now. As a result, a lot of rules are not in accordance with the lives of Armed Force soldiers. There are few legal experts (legal scholars) interested in studying military law because it has no economic value and it must be a member of the military to understand military law. The development of military law is now a necessity that is arguably very urgent, many violations committed by Armed Force Soldiers because the military legal system is inadequate to resolve legal problems that occur within the Armed Forces. Therefore, the research problems that can be formulated are: do military laws need to be developed and updated adjusting to the needs and development of Indonesian military society? What efforts can be made to develop military law to suit the personality and needs of the Indonesian military community? These problems are discussed in the discussion section of this paper.

Based on the aforementioned background, military law which grew and developed in Indonesia today is a legal product of the Dutch Colonial Government. Therefore, it is no longer relevant for Armed Force Soldiers because it contains many colonialism values that are no longer in accordance with the dignity of Armed Force soldiers. In solving the aforementioned 
problems, 3 (three) legal theories are used in this study, namely legal system theory, legal objective theory, and legal development theory.

\subsection{Legal System Theory}

The legal system theory was put forward by Lawrence M. Friedman, who said that the success or failure of law enforcement depends very much on three legal systems including the legal structure, the substance of the law, and legal culture. The legal structure concerns law enforcement officers, the substance of the law includes the set of laws, and the legal culture is a living law adopted by a community [2].

The development of military law is carried out, starting from reforming the legal system including the structure of military law enforcement institutions, which include: Superiors who have the right to punish (Ankum), Officer Submitting Case (Papera), Military Police (Pom) as investigators, Military Oditur, Military Judges, and Military Society Organization (Lemasmil). The substance of military law includes the rules of military law, the norms and patterns of actual behavior of military law instruments. The substance of military law concerns the applicable laws and regulations and has binding power so that it becomes a guideline for military law enforcement officials including: KUHPM, Military Discipline Law, Military criminal procedural law (Military Court), military administrative law, and military civil law. Meanwhile, the legal culture is the attitude and behavior of the military community (law enforcement habits) in enforcing the law for soldiers. It needs availability of law in the form of rules/norms/regulations, and guarantees for the realization of the rules into legal practice [3]. Therefore, the development of military law in Indonesia begins with the structuring of the legal system.

\subsection{Legal Purpose Theory}

Gustav Radbruch states there are three (3) basic values to create harmonization of the implementation of legal objectives to protect the community both actively and passively and to create a condition of society that takes place appropriately, and to strive for prevention of arbitrary efforts of law enforcement in order to realize order, peace and justice so that people's prosperity can be achieved. The first basic value is justice as one of the purposes of the law. Gustav Radbruch stated "recht ist wille zur gerechtigkeit" (law is the will for justice). The second basic value is the benefit of the law. Utilists believe that the purpose of law is merely to provide maximum benefit or happiness for as many citizens as possible. The third basic values is normative legal certainty that regulations are made and enacted to regulate clearly and logically so that they do not clash or cause norm conflicts [4].

\subsection{Development Law Theory}

Kusumaatmadja's Theory of Development Law was first coined by the assumption that law cannot play a role in changing society and there has been a change in the nature of people's thinking towards modern law. Kusumaatmadja stated that law is a tool to maintain order in society. Another goal of law is the attainment of justice of different content and size, according to the development of society. In order to gain the order situation, legal certainty must be sought in the community. According to Mochtar Kusumaatmadja, law is expected to function as a means of community renewal or a means of development (law as a tool of social engineering) [5]. The Theory of Development Law created by Mochtar Kusumaatmadja shows 
that there are 2 (two) dimensions as its core, namely first, order in the context of renewal or development which is seen as something absolutely absolute, and secondly, law in the sense of rules or regulations can function as a tool the regulator or means of development desired for renewal.

\section{Method}

Research is an activity to analyze and construct law methodologically, systematically and consistently [6] to search for and find legal principles in order to answer legal issues according to the prescriptive character of legal science [7]. The method chosen to analyze the problem of the conception of the development of military law in Indonesia is normative juridical which examines the norms of military law both legislation on military discipline law, military criminal law, military criminal procedural law, military constitutional law, military administrative law military, and military civil law with a statutory approach and a conceptual approach.

\section{Result and Discussion}

Military law has the meaning implied in the two words that make it up, namely the words military and law. Law means a series of rules, regulations, orders, both written and unwritten that determine or regulate the legal relations between members of the community [8]. The word military comes from the word "miles" which means a "warrior" i.e. someone who is ready to fight. Thus the military means the people assigned to war. Military Law embraces both a penal code for the maintenance of disclosure of the army and administrative laws which provide the maintenance of the army.

Military law is the law regarding military and army life. Therefore, military law consists of norms derived from various fields of law such as civil law, criminal law, state administrative law, international law in which the objects are military lives. In addition, military law is a special part of various fields of law that only applies to the military and the army [9].

\subsection{The Scope of Military Law}

Military law in force in Indonesia at the moment is largely derived from legislation legacy from the Dutch East Indies Colonial Government which was much influenced by Continental European Military Law. The results of the study of the legislation products show that Military Law in Indonesia covers military disciplinary law, military penitentiary law, military state administration law, military administrative law and armed dispute law/humanitarian law which specifically regulates the life of the Indonesian military. The norms that specifically regulate the rules that apply to the military are compiled into a single unit so that they are easy to learn. The laws and regulations relating to each of these legal fields are no longer valid, some are out of date, but most still apply, of course, after changes and additions are made according to the nature of independence.

In the military (Armed Forces) environment, it can be said that military law has not been popular in the community, which means that it has not been fully recognized by the military community. In military education, the cadets are only taught at glance about Military Discipline Law, Military Criminal Law and the Law of Armed Disputes. Special experience in the field of military law can only be obtained through bachelor degree (S-1) education at the Military Law College (STHM). In addition, if someone is interested in military law, he/she 
will write a final project, thesis, or dissertation with the object of research related to military law.

\subsection{History of the Development of Military Law in Indonesia}

The history of military law in Indonesia was influenced by the arrival of the Dutch in the archipelago which can be divided into 4 (four) periods, namely the era of Verenigde OostIndische Compagnie (VOC), the era of the beginning of the Dutch Government, the period of the Japanese Government, and the Period of Indonesian Independence [10].

i. Military Law of the VOC Period

In trade competition, the VOC engaged in battles with the Spaniards and Portuguese so that the Dutch Government granted freedom to the VOC to arm themselves and gave them the right to build fortresses on the archipelago's mainland. Therefore, the VOC had the right to hold government apparatus and make the necessary regulations. The Dutch government allowed the VOC to have its own army and enforced Dutch military law (articulbrieven) for VOC troops in the archipelago. The VOC army was unable to control the vast archipelago territory, so in 1799 , the VOC government was taken over by the Dutch Government.

ii. Military Law in the Beginning of the Dutch East Indies Government In 1803, the Dutch Government was invaded by France under Napoleon's control and appointed Lodewijk Napoleon as king of the Netherlands. To prevent the Dutch colony from falling into French hands, in 1816, the British invaded the archipelago led by Lord Minto and assisted by Thomas Stanford Raffles who was later appointed as GovernorGeneral in the former Dutch colony. Raffles allowed the indigenous people to live under their customary law, while the British army was under British Military Law. In 1816, the former Dutch colony controlled by the British was handed back to the Dutch Government along with the Dutch occupation forces sent directly from the Netherlands to the Archipelago. They brought military law in the form of Criminee Wetboek voor de Landmacht (Book of the Criminal Code of the Army), Rechtspleging bij de Landmaccht (Judicial Army), and Reglement van Krijgstucht (Military Disciplinary Regulations). On January 1, 1923, Wetboek van Militair Starfrecht (KUHPM) and Wetboek op de Krijgstucht (KUHDM) applied in the Netherlands. While, on October 1, 1934, KUPM and KUHDM were enforced in the Dutch East Indies by Decree of the General Governor dated on March 25, 1934 statsblad 1934, Number 337. Thus, since 1934, military law in force in the Dutch East Indies included the KUHPM (Wetboek van Militair Strafrecht), the KUHDM (Wetboek op de Krijgstucht), the Army Court (Rechtspleging bij de Landmacht), Law on the Supreme Military Court in the Indies (Provisionele Instructie voor), the Miltaire Gerechtshof van Nederland, and the provisions on the rule of Military Justice in the Dutch East Indies (Bepalingen Betreffende de Rechtmacht van de militaire Rechter in Nederlands Indie).

iii. Military Law during the Japanese occupation

On December 8, 1941, the Pacific War broke out between Japan and the United States and Britain. In a short time, Japan succeeded in occupying the Philippines, Formusa (Taiwan), Vietnam, Malaysia, Singapore, and the Dutch East Indies. In March 1942, the Government of the Dutch East Indies was taken over by the Japanese Military by bringing its own military laws that apply to Heihio, Gyugun, and Peta. 
iv. Military Law after Indonesia's Independence

After the Proclamation of Independence on August 17, 1945, the Government of Indonesia issued Government Regulation No. 2/1945 that all existing regulations remained in effect as long as a replacement had not been held. At that time, all regulations (military law) issued by the Dutch East Indies Government were applied to the Indonesian military. In 1946, the Government of Indonesia issued the Law No. 7/1946 on Army Courts, given the number of violations committed by members of the army. In 1947, the Law No. 39/1947 on the Army Criminal Code was issued. During 1945-1949, the Indonesian Government succeeded issued the Law No. 7/1946 on Army Courts, Law No. 8/1946 on Criminal Procedure Regulations at Army Courts, Law No. 31/1947 on Army Courts, Law No. 47/1947 on Army Imprisonment, Law Number 39/1947 on the Army Criminal Code, Law Number 490 of 1947 on KUHDT, and Government Regulation No. 24/1948 on Regulation of Army Discipline.

\subsection{Expected Conception of Military Law}

Indonesian Military Law is a sub-system of national law as a system. This means that the struggle of the soldiers who have sacrificed their lives to defend and preserve the Pancasila and the 1945 Constitution will not be betrayed. They have taken a rest in peace, because "knowing" that the struggle is still continuing. Apart from that, in the context of the development of military law in Indonesia, there are three main military principles that must be followed, namely:

3.3.1 Principles of the implementation of national security and defense. The principles of national defense and security include (1) the principle of universality to implement national defense and security; (2) the principle of populitism, i.e. the participation of all citizens in the defense and security; (3) the principle of territoriality, i.e. every inch of archipelago is the foundation of resistance which is, if necessary, in the form of continuous resistance of guerrilla;

(4) the principle of not recognizing surrender in maintaining sovereignty and maintaining the territorial integrity of the Unitary State of the Republic of Indonesia (NKRI); (5) the principle of prioritizing love for the motherland rather than peace; (6) principle of active defensive-offensive or active defensive; and (7) principle of esprit de corps, (although it must be based on that in the international political arena, there are no permanent friends or opponents).

3.3.2 Principles in the field of military organization, including: (1) the principle of single command; (2) the principle of homogeneous assignment; (3) the principle of delegation of authority; (4) the principle of spanned and spent of control; (5) the principle of the chain of command; (6) the principle of flexibility; (7) the principle of mobility; (8) the principle of simplicity; and (9) the principle of self-provisioning (self sufficiency).

3.3.3 Principles in the field of Armed Disputes, including: (1) the principle of reciprocity; (2) the principle of reprisal; (3) the principle of proportionality (balance); (4) the principle of equal rights and degrees, does not interfere in the affairs of other people's lands and upholds human dignity.

In the event of an incompatibility between general law and military law, it is seen from its urgency, especially for the country's existence, that Indonesian military law takes 
precedence. For this development, it is very important to pay attention to the history of the TNI which grew and developed through a process that is very unique to Indonesia. Guiding the good things from history does not necessarily have to be regarded as something that likes to go back to a time of emergency/war/danger. It could be also considered something that likes to inflame an emergency situation. Weaknesses and strengths obtained from the history of military law in Indonesia can be used as a mirror so that this nation does not fall into the same mistakes. Therefore, this nation can move faster because it utilizes things that are beneficial to the growth and development of the Indonesian nation. Douglas Mac Arthur states "if there is one thing I have learned during my long years of experience, it is that if we would correctly solve the problem of the present and chart a safe course into the future. We must study and weigh and understand the manifold lessons of which history is the great - indeed the onlycompetent teacher. For as cicero put it eighty years before the birth of Christ. Not to know what happened before one was born is always to be a child"'[11].

\subsection{Development of a Military Law system.}

The development of military law is an effort to form a new law in order to renew positive laws about military life. Updating means replacing the old military law with the new law. Reform of military law is in the same sense as the development of military law based on and sourced from the Pancasila and the 1945 Constitution. As a nation that has been independent since 17 August 1945 (more than 75 years), it should have its own national law products to meet the needs of the military community. The current military legal system is still limited to ideals. There is no certainty when there is a change in a better direction to be used as a guide for the military community (TNI) towards a better direction for the sake of order for members of the TNI.

One thing that needs attention in the development of military law must be based on the foundations and ideals contained in the military's moral consciousness and ideals. Military law as an embodiment of military life values is expected to be present to protect every member of the military. The development of military law is directed at the realization of a national-scale military law system that serves the interests of the TNI by adjusting overall legal material that originates from the Pancasila and the 1945 Constitution. The development of military law is expected to be able to change all kinds of laws on Dutch colonial products to be replaced with national law products.

The development of military law is expected to be a change and renewal of the legal system which includes changes in the structure, culture, and substance of military law itself. The construction of a military legal structure can begin with the establishment of adequate legal institutions to enforce the law by updating the Ankum, Papera, Pom, Military Oditur, Military Judges and Lemasmil systems. In law enforcement, law enforcers should be more humanistic and protective and provide legal awareness to soldiers who violate them, so they are reluctant to repeat violations of the law. This is in accordance with the principles of law enforcement in Indonesia, which are legal guidance and awareness, instead of deterrence. Thus, the development of Indonesian military law began with the improvement of the character of law enforcers. Culturally, the military community (members of the TNI) expects to get legal protection for their attitudes and behavior, so that justice and benefits can be created in the formation of the substance of military law.

The development of military law can be seen from the renewal of legal culture which refers to the values and hopes or dreams of the Indonesian military community (TNI). In the meantime, military justice is very easy to dismiss military members, without considering the 
interests of military organizations, military interests, and the interests of the nation and state. Recruiting a citizen into a TNI soldier is very expensive, if many soldiers are fired, there will be a lot of loss to the nation and state. Culturally, members of the military are always educated and taught to be accustomed to acting hard, decisive, and highly disciplined.

The development of the substance of military law is carried out through the reform mechanism of military legislation such as the reform of the KUHPM, the renewal of the Law on Military Justice, the reform of military administrative law, and the issuance of military civil law. At present, Law Number 31/1997 on Military Courts is still mixed with Military Administrative Courts, so that it has been enacted since the Law No. 23/1997 on Military Administrative Courts. This greatly interferes the sense of justice of the military community whose rights to seek justice in the field of military administrative law could not be channeled. Thus, substantially, there needs to be an update of all types of legislation governing military life that needs to be updated. Therefore, there is no arbitrariness in the actions taken by the unit commander against members. The process of issuing laws and regulations can be realized by means and methods that are definite and standard that bind all institutions authorized to make military laws and regulations and improve coordination of the process of issuing laws and regulations of military legislation. There is a need to update Law No. 34/2004 on the Indonesian National Army, because the administrative law is mixed with the Criminal Law so that it does not provide legal certainty.

\subsection{Development of Military Law in accordance with legal objectives.}

Gustav Radbruch stated that the purposes of law are justice, certainty, and expediency. At the beginning, Gustav Radbruch placed legal certainty in the main position, but after he saw the fact that in Germany under Nazi rule legalized the practice of inhuman warfare during World War II, Radbruch refined his theory by placing justice first and foremost most important than the certainty and usefulness of the law.

In the development of military law, the value of benefits is placed first by considering the interests of military organizations, military interests, the principle of unity of command, chain of command. Sentencing of violating soldiers considers the benefits of the aspects of law enforcement. Unlawful enforcement and enforcement will weaken the principle of unity of command and chain of command.

The purpose of expediency law is stated by Jeremy Bentham, John Stuart Mill, and Rudolf von Jhering. According to Bentham, the purpose of law is to provide maximum benefit and happiness to as many citizens as possible. The concept of military law development places expediency as the primary objective of law. The main measure of the aim of the law is as much happiness as possible for as many soldiers. Judgment of good-bad and fair-unfair of military law depends very much on its ability to give happiness to as many soldiers as possible. Benefit is defined as happiness. The purpose of the law according to Bentham is to provide a guarantee of happiness to each individual (the greatest happiness of the greatest number). The principle of expediency should be applied qualitatively because the quality of pleasure is always the same for every soldier. To realize the happiness of soldiers, each formation of military legal regulations, although achieving 4 (four) objectives, namely first, to provide subsistence; second, to provide abundant food; third, provide protection; and fourth, achieving equality.

Military regulations (military law) that can bring happiness to most military societies are seen as good legislation. The existence of the state in establishing military law is merely a tool to achieve ultimate benefits, i.e. the happiness of the majority of TNI soldiers. Thus, the development of military law that is expected by TNI soldiers is a rule that can provide 
happiness and improve the welfare of soldiers. It is because the daily life of TNI soldiers is hard, highly disciplined. If they are not given prosperity and happiness balanced with their lives, there will be many violations because TNI soldiers feel get unfair treatment from the state.

\section{Conclusion}

All in all, Military Law in force in Indonesia is largely a legacy of the Dutch Colonial Government; thus, it must be renewed according to the needs of the Indonesian Military community to avoid many violations committed by TNI Soldiers. The development of military law that is suitable for TNI soldiers to minimize the occurrence of law violations committed by TNI soldiers, so that military units become orderly, organized, and highly disciplined who are ready to carry out tasks in the field of national defense and security. Every TNI soldier must obey the rules of military law and carry out his duties and obligations according to the Oath of Warriors and guided by the Sapta Marga and the Eight Mandatory Forces of the TNI. The concept of the development of Indonesian military law is carried out through the renewal of the principles of the national defense and security, the principle of military organization, and the principle of armed disputes. The development of military law is expected to include reform of the military law system which includes reform of the structure, culture and substance of military law by sharpening the legal objectives of justice, expediency and legal certainty. The purpose of the development of military law is more emphasis on the usefulness towards justice through legal certainty.

\section{Acknowledgments}

The author wishes to thank the Head of Jayabaya University and Head of Faculty of Law for providing a facility to join International Conference in ICILS 2020 UNNES.

\section{References}

[1] Greensspan, Morris: The Modern Law of Land Warfare, Berkeley and Los Angeles. University of California Press. pp. 3 (1959)

[2] Friedman, Lawrence M.: The Legal System: A Social Science Perspective. New York: Russell Sage Foundation. pp. 5-6 (1975)

[3] Munir Fuadi. Jaminan Fidusia. Bandung: PT. Citra Aditya Bakti. pp.40 (2003)

[4] Achmad Ali: Menguak Teori Hukum (Legal Theory) dan Teori Peradilan (Judicialprudence) Volume 1 Cetakan ke-5. Jakarta: Kencana. pp. 288 (2013)

[5] Kusumaatmadja, Mochtar: Konsep-Konsep Hukum Dalam Pembangunan. Bandung: PT. Alumni. pp.13-14 (2002).

[5] Soekanto, Soerjono: Pengantar Penelitian Hukum. Jakarta: Universitas Indonesia.pp. 42 (1986)

[6] Marzuki, Peter Mahmud: Penelitian Hukum. Jakarta: Kencana. pp.35 (2011).

[7] H.A, Hafizh Dasuki: Ensklopedi Hukum Islam.Jakarta: FIK-IMA. pp.571 (1997).

[8] Tanya Bernard L.: Teori Hukum, Strategi Tertib Manusia Lintas Ruang dan Generasi. Yogyakarta. Genta Publishing. pp.129-130 (2010) 
[9] Sianturi, S.R.: Hukum Pidana Militer di Indonesia. Jakarta: Alumni AHAEMPETEHAEM. pp.13-15 (2010).

[10] Tambunan, A.S.S.: Hukum Militer Indonesia Suatu Pengantar. Jakarta: Pusat Studi Hukum Militer Sekolah Tinggi Hukum Militer. pp.44 (2005).

[11] Sianturi, S.R.: Pengenalan dan Pembangunan Hukum Militer Indonesia, Pidato Dies Natalis Akademi Hukum Militer- Perguruan Tinggi Hukum Militer. Jakarta: Alumni AHAEM-PETEHAEM. pp.45 (1985). 